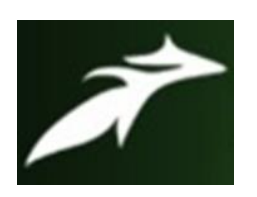

Kumari Shipra, International Journal of Advances in Agricultural Science and Technology,

Vol.1 Issue. 1, December- 2013, pg. 125-129

ISSN: 2348-1358

\title{
To Study the Adoption Level of Rural Women after getting Training on Mushroom Cultivation
}

\author{
Mrs. Kumari Shipra \\ Assistant Professor, Dept. of Home Science Extension Education, RAU, Pusa, Samastipur Bihar \\ DOI: 10.47856/ijaast.2013.v01i1.002
}

\section{Introduction}

Oyster mushrooms are the third largest cultivated mushroom in the world. China is the world leader in oyster production, contributes nearly 85 per cent of the total world production of about a million tons (Das and Kalita, 2006). The economic importance of the mushroom lies primarily in its use a food for human consumption. Mushroom cultivation can directly improve livelihoods through economic, nutritional and medicinal contributions. Mushroom is a popular food due to their special flavour, nutritive value and medicinal properties. It is rich in vitamin $C$ and $B$ complex and the protein content varies between 1.6 to 2.5 per cent. It has most of the mineral salts required by the human body. The niacin content is about ten times higher than any other vegetables. It has been reported by Rop et al. (2009) and Manikandan (2010). They provide high quality fats and low in carbohydrates and cholesterol, which is ideal for reducing body weight (Qumio et al., 1990)

Mushroom growing is one of the agricultural activities in which women can play a vital role without sacrificing their household responsibilities. Mushroom cultivation is simple, low cost and suitable for rural areas, is labour intensive and can provide employment in both the semi-urban and rural areas. Mushroom cultivation is an important subsidiary occupation for the landless and small farmers and can be adopted by them in leisure time. Mushroom being an indoor activities and can be cultivated by utilise vertical space giving high productivity per unit area and time. Mushroom cultivation is a low cost enterprise. With the changing life style food habits increased awareness in urban and semi urban are about health benefits of mushroom and increasing population. The mushroom consumption is increasing faster rate. It is an economical crop to cultivate, requiring low resources and area, can be grown throughout the world and all over the year from low-cost materials. There is tremendous potential and appeal for growing a highly nutritious food with excellent taste from substrates that are plentiful and not very expensive (Beetz and Kustudia, 2004). Also, it is very environmental friendly, capable of converting the lingo cellulosic waste materials into food, feed and fertilizers (Hadar et al., 1992; Jaradat, 2010). 


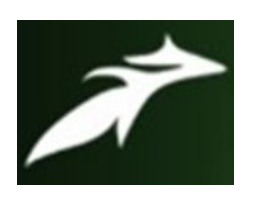

Kumari Shipra, International Journal of Advances in Agricultural Science and Technology,

Vol.1 Issue. 1, December- 2013, pg. 125-129

ISSN: 2348-1358

Promotion of mushroom cultivation could relieve pressure on land, increase food and nutritional security and uplift the status of women through earning additional income and in household decision making as far as concerned (Manju et al., 2012) [3] . Keeping in view the above facts the present study was conducted to find out the impact of mushroom cultivation by rural women and their adoption level after getting training in Samastipur district of Bihar.

\section{Methodology}

The study was conducted in Samastipur district of Bihar. There are 38 districts in state and the dissemination of mushroom technology is fast in all districts of state. Out of 38 districts, Samastipur district was selected purposively for the study because of the fact that DRPCAU is located in same district and there is a training centre at DRPCAU. All together there are 20 blocks in Samastipur Out of which Pusa and kalyanpur block have been selected for study purpose based on assumption that these block have the largest number of trained beneficiaries. Out of these only three villages were selected two from Pusa namely Birauli and Deopar and one from kalyanpur namely Ladhaura. A complete list of the beneficiaries who have undergone through training on mushroom cultivation from DRPCAU, Pusa was obtained from training centre. 25 beneficiaries respondents from each of three villages where purposely selected. Hence all total 75 respondents were selected, through random sampling. The data were collected by using pre structural interview schedule and were subjected to statistical analysis.

\section{Result and Discussion Adoption}

To assess the impact of mushroom cultivation training the adoption of the respondents were measured with the help of Standardized i.e. pre-training and post training. On the basis of adoption capability respondents was classified into three categories i.e. low (0-11) medium (12-22) and high (23-33) level of adoption presented in Table 1.

Table 1. Level of adoption before training

\begin{tabular}{|l|c|l|l|}
\hline Adoption level & $\begin{array}{l}\text { No. of } \\
\text { respondents }\end{array}$ & Percentage & Mean \\
\hline Low (0-10) & 36 & 48.00 & 10.56 \\
\hline Medium (12-22) & 30 & 40.00 & \\
\hline High (23-33) & 9 & 12.00 & \\
\hline Total & 75 & 100 & \\
\hline
\end{tabular}




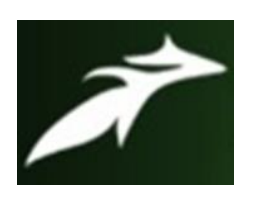

Kumari Shipra, International Journal of Advances in Agricultural Science and Technology,

Vol.1 Issue. 1, December- 2013, pg. 125-129

ISSN: 2348-1358

Table displays that about 48 percent of the respondents had low level of adoption followed by 40 percent respondents having medium level of adoption only 12 percent of respondents had shown high level of adoption before the exposure of mushroom training programme and their mean score was found to be 10.56 .

Table 2. Level of adoption after training

\begin{tabular}{|l|c|l|l|}
\hline Adoption level & $\begin{array}{l}\text { No. of } \\
\text { respondents }\end{array}$ & Percentage & Mean \\
\hline Low (0-10) & 24 & 32.00 & \\
\hline Medium (12-22) & 37 & 49.34 & 18.77 \\
\hline High (23-33) & 14 & 18.66 & \\
\hline Total & 75 & 100 & \\
\hline
\end{tabular}

This table revealed that out of total beneficiaries about 49.34 percent of respondents had found in medium level of adoption followed by 32.00 percent low level of adoption, only 18.66 percent of the respondents had high level of adoption after training. The mean score was found to be 18-77 after getting the training.

\section{Change in adoption}

Adoption is a mental process through which an individual passes from first hearing about an innovation to final adoption. The change in adoption level of respondent score was obtained after training i.e. post training score. The number of respondents by change in adoption score presented in Table 3.

Table 3. Change in adoption level respondents after training

\begin{tabular}{|l|c|l|l|}
\hline Adoption level & $\begin{array}{l}\text { No. of } \\
\text { respondents }\end{array}$ & Percentage & Mean \\
\hline Low (0-10) & 44 & 58.00 & \\
\hline Medium (12-22) & 29 & 38.67 & 8.21 \\
\hline High (23-33) & 03 & 02.67 & \\
\hline Total & 75 & 100 & \\
\hline
\end{tabular}

It Could be seen from the Table 3. that change in adoption of respondents was low i.e.58.66 percent followed by 38.67 percent having medium level of adoption and only 2.67 percent of the respondents showing high level of change in adoption. This table also indicates the mean score of respondents to change in adoption was found to be 8.21. 


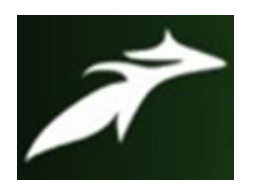

Kumari Shipra, International Journal of Advances in Agricultural Science and Technology,

Vol.1 Issue. 1, December- 2013, pg. 125-129

ISSN: 2348-1358

\section{Impact of training programme on economical status of respondents income level}

In the present study the impact of mushroom cultivation training programme on economical status of rural women and their income has been derived from different sources namely. Poultry/birds, pigs, cow, buffaloes, agriculture and mushroom production. Mushroom income was calculated on the basis of harvest price whereas income from different source of rural women through various training like mushroom cultivation, bee-keeping and through different production system. Hence it is a mandatory to assess the income level of rural women about pre- training and post training. For the purpose income from different source and mushroom cultivation was quantified and average income for different categories was calculated in before training and after training. Thus farm size-wise average income being presented in Table 4.

Table 4. Average income level of respondents per annum from different source included Mushroom Cultivation.

\begin{tabular}{|c|c|c|c|c|}
\hline Categories & $\begin{array}{c}\text { No. of } \\
\text { respondent }\end{array}$ & $\begin{array}{c}\text { Income in } \\
\text { rupees before } \\
\text { training }\end{array}$ & $\begin{array}{c}\text { Income in } \\
\text { rupees after } \\
\text { training }\end{array}$ & Difference \\
\hline $\begin{array}{c}\text { Below poverty line (up } \\
\text { to 12000) }\end{array}$ & 32 & 10875.00 & 13812.5 & 2937.5 \\
Low (12000-25000) & 22 & 22454.54 & 26709.09 & 4254.55 \\
$\begin{array}{c}\text { Medium (25000- } \\
50000)\end{array}$ & 15 & 27933.33 & 30940.00 & 3006.67 \\
High (50000 \& above) & 06 & 52333.33 & 54366.66 & 2033.33 \\
\hline Total & $\mathbf{7 5}$ & $\mathbf{1 1 3 5 9 6 . 2 2}$ & $\mathbf{1 2 5 8 2 8 . 2 5}$ & $\mathbf{1 2 2 3 2 . 0 5}$ \\
\hline
\end{tabular}

This table indicated that respondents involved in mushroom cultivation training Programme has belonged to low income groups and their average income from different source was i.e. 22,454.54 Rs/annum before training and after growing mushroom their income level increased up to $26,709.09$ followed by medium income group of respondents i.e 27,933.33 Rs/annum before training and after getting training their income level increase up to 30,940 Rs/annum. This table also indicated that even below poverty line women involved in mushroom cultivation training had their income level increase from 10.75.00 Rs/annum to 13.812.5 Rs/annum. In case of high income group their production after getting training it increase from 52,333.33 Rs/annum to $54,366.66$ Rs/annum so it may be attributed that low income group had involved in mushroom cultivation more efficiency then other income group because its cultivation require no more space. Less expensive and even technology is very simple that's why even landless women or low income group of respondents prefer to do it with more interest and enthusian. 


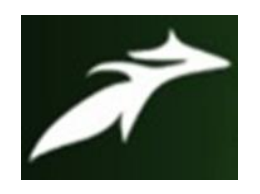

Kumari Shipra, International Journal of Advances in Agricultural Science and Technology,

Vol.1 Issue. 1, December- 2013, pg. 125-129

ISSN: 2348-1358

\section{Conclusion}

It can be concluded that Pre-training adoption, the mean score of the respondents was found to be 10.56. Whereas post-training adoption, the finding Indicated that the post training adoption, mean score of respondents was found to be18.77. Further finding indicated that change in adoption was low i.e. 58.66 percent of respondents 38.67 percent had medium level of adoption, only 2.67 percent of the respondents had high level of adoption about Mushroom cultivation. The difference of their mean score of respondents were found to be 8.21 and their economical status also improve after adoption of that technology.

\section{References}

[1]. Srivastava, K K, Bateth, L.S, and SankerJ, D. 1995-1996.Impact 0f farmers training centre on knowledge adoption and diffusion of improved farm practices Guj. J. Extn.edu. $6^{\text {th }}$ and $7^{\text {th }} 188-196$.

[2]. Singh, S, Makhija V,K and Singh, S 1999 knowledge and adoption of improved mushroom cultivation practices in Haryana Mushroom Research, 8(53-54).

[3]. Verma et al. (1993) in his study found that rural women had gained sufficient level of knowledge after training exposure in different improved home practices.

[4]. Chang S.T Lace O.W and Chattopadhya RN (2000) Use of wild grasses as substract for cultivation of oyster mushroom in south west Bengal, Mushroom Research, 9(2) 95-99.

[5]. Sanyogita (2000) found that a training on oyster mushroom cultivation was formulated for unemployed youth and homemakers following the system approach to training in india. The impact of training was quantified by reaction, learning and performance evaluation of training.

[6]. Bano, Z and Srivastava H.C (1962) Studies on Cultivation of pleurotus species on paddy straw. Food Science.

[7]. Rop et al. (2009) and Manikandan (2010) The niacin content is about ten times higher than any other vegetables.

[8]. (Hadar et al., 1992; Jaradat, 2010). It has been reported by it is very environmental friendly, capable of converting the lingo cellulosic waste materials into food, feed and fertilizers.

[9]. (Manju et al., 2012); Promotion of mushroom cultivation could relieve pressure on land, increase food and nutritional security and uplift the status of women through earning additional income and in household decision making as far as concerned. 